\title{
How To Cope With A Plant Closing
}

\author{
Semoon Chang \\ University of South Alabama \\ Mobile, Alabama
}

The reality of business closing is complex. One extreme is the way the Baltimore Colts closed their operations in Baltimore. They loaded in moving vans all the Colts' records and equipment and left Baltimore toward Indianapolis in the darkness of the early morning hours of March 29, 1984. They did not let anyone know in Baltimore [7]. The other extreme is the December 18, 1991 announcement by the General Motors of its plan to close six assembly plants and 15 component operations by 1995 , thereby reducing its work force by 74,000 in the process. The 1990 s is also experiencing the closing of many military bases owing to the demise of the Soviet Union. The closing of plants and military bases is only the beginning of problems for communities that have to cope with the loss of jobs and revenue. The term, plant closing, in this paper is used in a loose way to encompass closings of plants, businesses, and military bases that lead to the layoff of a large number of workers.

Discussed in this paper are approaches through which a community may be able to ease the adverse impact of a plant closing. These approaches include an active negotiation with the company in such a way to make the transfer process of displaced workers less painful, as well as a utilization of the closed plant for other productive uses. There is no easy or quick way of replacing the closing plant. This paper is intended to provide information that can assist communities in adapting to the closed plant.

\section{Successful Company Programs}

Many companies that have closed a plant in the past provided their displaced employees with a variety of assistance. Communities may learn from these successful programs and use them as the basis for negotiation with the firm closing the plant.

Employee assistance programs are of four types: severance pay, extension of health care benefits, outplacement assistance, and counseling services. Severance pay is a payment that a company makes to its employees who no longer work for the company. Companies may continue to pay workers their regular wages for a certain period of time beyond termination of their employment. Alternatively, one-time payment based on a certain formula may be made upon termination of employment. Extension of health care benefits is probably the most important issue with most displaced workers. A desirable program for displaced workers would be that the extension of health care benefits covers dependents as well as workers and lasts until displaced workers can make alternative arrangements. Outplacement assistance includes 
relocation of workers to other locations of the same company, job-search assistance outside the company, resume preparation, and letters to other companies. A successful outplacement assistance requires an advance notification of plant closing. Counseling services are not as important as the three major types of assistance described in the above. Studies have found that workers are not interested in counseling because economic conditions leading to a plant closing tend to cause employees to become reconciled to their fate long before they lose their jobs [2].

In 1986, the Conference Board published a research report in which six cases of plant closings were investigated in depth. The six cases are Armoco Steelworks (Houston, Texas), Ford Motor Company (San Jose, California), GTE-Lenkurt (San Carlos, California), International Harvester, Corporate Headquarters (Chicago, Illinois), and Levi Strauss \& Company (Denison, Texas) [2]. All these six cases represented successful programs in which companies went an extra mile to help their displaced workers.

According to the report by the Conference Board, successful plant closing programs had the following six characteristics [2]. First, a large percentage of displaced workers was offered a transfer to another location of the same company. Second, outplacement was provided for those who were not offered or did not accept another job. Third, the relation between displaced employees and the company was harmonious. Fourth, workers did not file lawsuits. Fifth, severance benefits were liberal and health insurance coverage was extended beyond the plant closing date. Finally, good community relations were maintained during the closing process.

\section{An Exemplary Case}

Wapakoneta is a community of 8,500, located on I-75 between Toledo and Dayton, Ohio. Fisher Cheese, located in Wapakoneta, was owned by Amfac, Inc. of San Francisco. When 367 employees of Fisher Cheese made their way to the November 1986 meetings held at several locations throughout the community, they were wondering what the future held for the company and for themselves. At these meetings, the employees were told that Fisher Cheese was bought by Borden as of November 18, 1986. Borden subsequently closed the plant, and all 367 employees lost their jobs. Plant closing was not announced in advance because of the alleged sensitivity of the negotiations and vulnerability of food products [10].

Fisher Cheese is a classic example of how a good company handles a plant closing. What Amfac did as the owner of Fisher Cheese for its former employees was praised highly by many including the then Ohio's Lt. Governor Paul Leonard, who said, "They are truly setting a tone of leadership." The company continued to pay for six weeks; made severance pay of a week for each year's work; continued life and medical insurance benefits for 3 months; gave an option to extend the insurance up to 18 months; provided career counseling; provided a job placement center with 7 people, which found jobs for 332 people when it finally closed in May, 1987; donated $\$ 30,000$ to church-sponsored emergency food services; and contributed $\$ 200,000$ to the city for economic development. 


\section{Use of Displaced Physical Resources}

Displaced resources are of two types; the abandoned plant facility that may be called displaced physical resources, and the laid-off workers referred to as displaced human resources. Displaced physical resources are discussed in this section using the case of the closed Goodyear plant in Windsor, Vermont.

On May 3, 1987, the Goodyear Tire and Rubber Company plant closed its 50year-old Windsor plant and laid off 350 people. For a town of only about 4,100 people, the closing of the Goodyear plant left Windsor with a "gaping hole" [8]. As is often the case with the closing of a major plant, Goodyear donated the old plant and the site to the town. Windsor developed the surrounding area into an industrial park, taking advantage of its proximity to an interstate highway and wages that were slightly lower than those in nearby Boston. In less than two years, a trucking company and a marble company had settled into the industrial park, while several small employers moved into the old Goodyear plant.

The long-term impact of a plant closing varies with the community. If a community is a company town and the company closes its doors, the impact would be devastating. In most cases, however, the long-term impact of plant closing has not been found to be disastrous. Detailed case studies on the long-term impact of plant closing on the community are limited mostly to the closing of military bases, although conclusions are similar in limited studies of nonmilitary plant closing [8].

Many old military bases are transformed into industrial parks and the long-term impact of the base closing has been encouraging. Gazzano reached this conclusion after the review of base closings in Quonset Point (Rhode Island), Chippewa County (Michigan), Selma (Alabama), Fort Holabard in Baltimore, and the Boston Naval Annex [5]. A study by MacKinnon reached a more positive conclusion by stating that after a brief lull, local economies bounced back with renewed vigor and there was no long term adverse impact on local economies [9]. MacKinnon's study is based on the 1960s' closings of Air Force bases in Bangor (Maine), Lincoln (Nebraska), Reno (Nevada), Roswell (New Mexico), Harrisburg (Pennsylvania), Greenville (South Carolina), and Amarillo (Texas).

\section{Use of Displaced Human Resources}

Although there are exceptions, many displaced workers eventually find jobs but at a lower wage. Sixteen months after the closing of the Goodyear plant, the unemployment rate in Windsor returned to the pre-closing level. Numerous adjustments had to be made by the former Goodyear employees, however. Mr. Gary Buealmont, who was 30 years old, spent 10 months looking for a job before becoming a computer consultant. Sherman Carter, who was Goodyear's plant manager, started a construction company with his son. Bruce Curtis, who had been at the plant for 35 years, later managed the Windsor Country Club at a considerable salary reduction. Joe Dart, who had worked at the plant for 18 years, became a teacher. 
The community experiencing a plant closing may seek financial assistance from the Job Training Partnership Act in order to help displaced workers find jobs. Title III of the Job Training Partnership Act specifically addresses the issue of assisting displaced workers from plant closing or mass layoff. Section 302-(a) authorized each state to establish procedures to identify eligible individuals who have been terminated or have received a notice of termination as a result of any permanent closure of a plant or facility. In many local areas, the identification process and the actual assistance are handled through the Private Industry Council (PIC) and the state employment agency.

The types of assistance authorized under this Act are spelled out in Section 303. Financial assistance provided to states under this Act may be used to assist eligible individuals to obtain unsubsidized employment through training and related employment services, which include but are not limited to: (1) job search assistance, including job clubs; (2) job development; (3) training in job skills for which demand exceeds supply; (4) supportive services, including commuting assistance and financial and personal counseling; (5) pre-layoff assistance; (6) relocation assistance; and (7) programs conducted in cooperation with employers or labor organizations to provide early intervention in the event of closures of plants or facilities.

\section{Plant Closing Notification Act}

Although direct assistance is not likely, communities need to be aware of the Worker Adjustment and Retraining Notification Act of 1988, popularly known as the Plant Closing Notification Act. According to the Act, an employer cannot order a plant closing or mass layoff until the end of a 60-day period after the employer serves written notice of such an order. The law applies to businesses that employ 100 or more workers excluding part-time workers. Before the passage of the Act, the percentage of no advance notice was high, ranging from 47 percent to 64 percent, depending on the period of study. The period of advance notice, when provided, was also short, averaging between 18 days if specific dates of lay-off were given, to 46 days if the notice was given without specifying the exact date of termination [3].

The legislative process, which required a compromise between businesses that opposed the law and labor unions that favored it, led to many exceptions thus weakening the law considerably. For example, an employer can close operations before the conclusion of the 60-day period under two circumstances. The first is that the employer was actively seeking capital or business, which, if obtained, would have enabled the employer to avoid or postpone the shutdown. In this case the employer should have believed "reasonably and in good faith" that giving the required advance notice would have precluded the employer from obtaining the needed capital or business. The second is that the closing or mass layoff is caused by business circumstances that were not reasonably foreseeable as of the time the notice would have been required.

Another example of exceptions relates to temporary layoffs made to be permanent. Suppose that a business lays off employees by announcing that the layoff would 
last less than 6 months but extends it beyond 6 months. In this case, the employer would not violate the Notification Act if the extension beyond 6 months is caused by unforeseen business circumstances, including changes in price or cost that were not reasonably foreseeable at the time of the initial layoff. This exception is potentially a powerful excuse for an employer to bend the 6-month layoff rule. Consider that businesses often reduce, or are forced to reduce, the number of employees long before plant closing becomes the reality ([8], [2]). When Goodyear plant in Windsor, Vermont, closed its operations on May 3, 1987, its work force was down to 350 from its peak 800. When International Harvester plant in Louisville, Kentucky, was closed on August 3,1984, its work force was reduced to 727 from its peak 6,500. When Amoco Steelworks in Houston closed its doors on January 27, 1984, the number of employees was 1,100 down from its peak 4,500. It can easily be claimed that the gradual decrease in the number of employees at these plants was caused by business circumstances that were not reasonably foreseeable.

The central issue in the Congressional discussion of the Notification Act was whether advantages of such requirement outweigh disadvantages. Major economic advantages of the bill, supporters claimed, were (1) shortening the duration of unemployment after layoff or plant closing, and (2) saving of the unemployment benefit payments. Major disadvantages, opponents of the bill claimed, were (1) the possibility of shirking behavior by employees between notification and termination, and (2) the exit of highly qualified workers prior to the closing or layoff date. Empirical findings are virtually unanimous in that advance notice significantly reduces the duration of unemployment of those notified workers ([4], [1], [11]). These studies also conclude that the shirking behavior of notified workers is not significant, although the loss of productivity owing to the early exit of qualified workers can be significant.

\section{Summary}

Communities may cope with a plant closing or mass layoff (1) by negotiating with the company for maximum assistance to displaced workers and the community itself, and (2) by developing plans to utilize displaced physical and human resources. In negotiating with the company, community leaders should pursue, at least, the following four types of employee assistance; severance pay, extension of health care benefits, outplacement assistance, and counseling services. Communities may seek financial assistance for displaced workers through the Job Training Partnership Act. Title III of the Job Training Partnership Act specifically addresses the issue of assisting displaced workers from a plant closing or mass layoff.

The displaced plant site usually has locational advantages such as a proximity to good transportation infrastructure. The site therefore may be a candidate for development as an industrial park. Although the short-term impact of a plant closing can be devastating, its long-term impact has been found to be encouraging. According to the Worker Adjustment and Retraining Notification Act of 1988, an employer with 100 or more full-time workers has to provide a 60 -day advance notice before 
closing a plant. Studies indicate that advance notice significantly reduces the duration of unemployment of those notified workers, and that the loss of productivity owing to the early exit of qualified workers can be significant.

\section{References}

1. Addison, John T. and Portugal, Pedro. "The Effect of Advance Notification of Plant Closings on Unemployment," Industrial Labor Relations Review, Vol. 41 (October 1987), pp. 3-16.

2. Berenbeim, Ronald E. Company Programs to Ease the Impact of Shutdowns, New York: The Conference Board (1986).

3. Brown, Sharon P. "How Often Do Workers Receive Advance Notice of Layoffs?" Monthly Labor Review, Vol. 110 (June 1987), pp. 13-17.

4. Folbre, Nancy R., Leighton, Julia L, and Roderick, Melissa R. "Plant Closings and Their Regulation in Maine, 1971-1982," Industrial Labor Relations Review, Vol. 37 (January 1984), pp. 185-96.

5. Gazzano, Louis A. "Old Military Bases Never Die: They Become Industrial Parks," Barron's November 3, (1986), p. 57.

6. General Accounting Office, Plant Closings: Information on Advance Notice and Assistance to Displaced Workers, GAO-HRD87-86BR, April 17 (1987).

7. Harris, David. The League: The Rise and Decline of the NFL, Toronto, Canada: Bantam Books, (1986).

8. Johnson, Sally. "Town Survives Without a Company," The New York Times, September 18 (Sunday), (1988), p. 52.

9. MacKinnon, David A. "Military Base Closures: Long Range Economic Effects and the Implications for Industrial Development," AIDC Journal, Vol. 13 (July 1978), pp. 7-41.

10. Matte, Harry. "Cheese Plant Closing Opens New Doors," Personnel Administrator, Vol. 33 (January 1988), pp. 52-56.

11. Mishel, Lawrence R. "Advance Notice of Plant Closings: Benefits Outweigh the Costs," Challenge, Vol. 31 (July/August 1988), pp. 58-61.

12. United States Code Congressional and Administrative News, 97th Congress-Second Session, Vol. 1, "Job Training Partnership Act," Public Law 97-300 (S. 2036), October 13, 1982, 96STAT. (1982), pp. 1322-1399.

13. U.S. Department of Labor, Bureau of Labor Statistics, Permanent Mass Layoffs and Plant Closings (1987), Washington, D.C.: U.S. Government Printing Office, July 1988. 